\title{
THERMAL AND OXYGEN CONDITIONS IN CARP PONDS DURING THE SUMMER PERIOD
}

\author{
Magdalena Wiśnios' ${ }^{1}$, Włodzimierz Kanownik ${ }^{1}$ \\ 1 Department of Land Reclamation and Environmental Development, University of Agriculture in Krakow, \\ Mickiewicza Av. 24-28, 30-059 Krakow, Poland, e-mail: rmkanown@cyf-kr.edu.pl
}

Received: 2015.09 .16

Accepted: 2015.10.06 Published: 2015.11.10

\begin{abstract}
The work presents changes of oxygen indices in carp ponds during the summer season. The basis of the research were regular water tests conducted in two ponds: Mydlniki II intended for carp farming in the second year of fish production cycle and Bocian used for carp farming in the third (final) year of breeding. The temperature of pond water in July and August was optimal for development and farming of cyprinid fish and ranged from 16.6 to $30.5^{\circ} \mathrm{C}$. The lowest value of oxygen dissolved in water $\left(6.4 \mathrm{mg} \cdot \mathrm{dm}^{-3}\right)$ was registered in Mydlniki II pond and was higher than the oxygen optimum for carp $\left(5 \mathrm{mg} \cdot \mathrm{dm}^{-3}\right)$. Oxygen saturation in water of fish ponds exceeded the optimum upper limit value (168\%) on a few dates, however, it posed no lethal threat for fish. In August in Bocian pond oxygen saturation fell within the range of optimal values, creating better conditions for fish development. In the secondary pond (Mydlniki II) it was found that oxygen saturation in water on 12 dates was lower than the low optimal value $(96 \%)$.
\end{abstract}

Keywords: fish pond, dissolved oxygen, water temperature.

\section{INTRODUCTION}

The main source of dissolved oxygen in carp ponds is its diffusion from the atmosphere and photosynthesis constituting over $80 \%$ of oxygen incomes. However, the quality of photosynthesis is affected by a number of factors, among others: the temperature, solar radiation, water transparency but also by the content of nutrients and substances dissolved in water [Tokarczyk-Dorociak and Drabiński 2007, Jawecki and Krzemińska 2008]. Physicochemical characteristics of water in carp ponds undergoes constant dynamics [Gál et al. 2003, Kanclerz 2005, Raczyńska and Machula 2006, Kanownik 2010, Dulic et al. 2010]. Some of the water quality indices, such as dissolved oxygen content or degree of oxygen saturation are changing during the day, which is primarily influenced by the photosynthesis process [Jawecki et al. 2013, Kanownik and Policht-Latawiec 2015]. Because the dimension of photosynthesis is conditioned by the solar energy, the level of oxygen dissolved in carp pond is increasing all day while after sunset the amount of oxygen diminishes [Whetstone 2009]. Diversification of water oxygen saturation is strictly connected with physiological activity of fish and other aquatic organisms. Fluctuations of oxygen concentrations are the bigger, the more fertile the pond is. The degree of oxygen solubility is decreasing with increasing water temperature, which may cause a danger of insufficient amount of oxygen available to fish at their simultaneously intensified activity [Bieniarz et al. 2003]. The amount of dissolved oxygen and the water temperature are among the most important parameters conditioning the life of organisms in the aquatic environment [Lutnicka 2011, Łysak et al. 2002]. According to Krzyczkowski [2000] there is a correlation between these factors, the value of oxygen solubility diminishes with increasing water temperature. Although the dependence is statistically significant, the correlation coefficient reaches quite low value, rarely exceeding $r=0.5$ [Jawecki 2008]. It is strictly associated with pond warming at high air tem- 
perature which may cause faster algae and other phytoplankton organism blooms in ponds.

\section{MATERIALS AND METHODS}

In order to assess the dynamics of oxygen indices in carp ponds during the summer season, water tests were conducted in two ponds - a secondary pond Mydlniki II (second year in the fish farming cycle) and in Bocian production pond (third year of the cycle) at the Fishery Experimental Station of the University of Agriculture in Krakow. Measurements of the analyzed water indices were conducted daily between 10 a.m. and 12 p.m. for two months from 01.07 to 31.08.2012. The places for water sampling were localized by the outlet boxes. Field tests involved sample collection from the near-surface zone, about $0.20 \mathrm{~m}$ below the water table and from the near-bottom zone, about $0.20 \mathrm{~m}$ above the reservoir bottom. Water was sampled for analyses using bathometer. Water temperature $\left[{ }^{\circ} \mathrm{C}\right]$, dissolved oxygen content $\left[\mathrm{mg} \cdot \mathrm{dm}^{-3}\right]$, oxygen saturation in water [\%] were assessed in the collected samples by Elmetron CO-411 oxygen meter using electrochemical method. Additionally, air temperature was measured. The research was conducted in carp ponds located in Mydlniki $\left(50^{\circ} 05^{\prime} \mathrm{N}, 19^{\circ} 49^{\prime} \mathrm{E}\right)$ in the urban area of Kraków, Bronowice quarter. The fish ponds are fed by the Rudawa river, which is a second order river flowing into the Vistula.

\section{RESULTS}

Cyprinid fish farming in artificial ponds requires fulfilling certain conditions, among others proper water temperature, optimal content of dissolved oxygen and water saturation with oxygen in the reservoir. The paper presents an analysis of results obtained from two month measurements of two water oxygen indices and water temperature. On the basis of the collected data, the dynamics of the analyzed indices was described taking into consideration descriptive statistics and a correlation between the water temperature and its oxygen indices was demonstrated. Statistical analysis was conducted between the values of individual parameters in both ponds - secondary pond Mydlniki II and production pond Bocian.

On the basis of descriptive statistics it was found that water temperature revealed the lowest variability in the secondary pond (13\%) and oxygen saturation degree in the production pond $(8 \%)$, irrespectively of the depth of sample collection. Among the tested samples the greatest variability was observed for the degree of oxygen saturation where the changes are on the level of 28 and $30 \%$, respectively near the bottom and near the surface of Mydlniki II pond (Table 1).

The analysis of variation coefficient revealed that a similar variability of the values of the analyzed indices occurred near the reservoir surface than close to its bottom. The rule does not apply in Mydlniki II pond and only in case of water oxygen saturation and the content of dissolved

Table 1. Descriptive statistics of water quality parameters in carp ponds

\begin{tabular}{|c|c|c|c|c|c|c|}
\hline \multirow[b]{2}{*}{ Descriptive statistics } & \multicolumn{2}{|c|}{ Temperature $\left[{ }^{\circ} \mathrm{C}\right]$} & \multicolumn{2}{|c|}{ Dissolved oxygen $\left[\mathrm{mg} \cdot \mathrm{dm}^{-3}\right]$} & \multicolumn{2}{|c|}{ Oxygen saturation degree [\%] } \\
\hline & $\begin{array}{l}\text { near the } \\
\text { surface }\end{array}$ & $\begin{array}{c}\text { near the } \\
\text { bottom }\end{array}$ & $\begin{array}{l}\text { near the } \\
\text { surface }\end{array}$ & $\begin{array}{l}\text { near the } \\
\text { bottom }\end{array}$ & $\begin{array}{l}\text { near the } \\
\text { surface }\end{array}$ & $\begin{array}{c}\text { near the } \\
\text { bottom }\end{array}$ \\
\hline \multicolumn{7}{|c|}{ Mydlniki II Pond } \\
\hline Average & 24.6 & 24.2 & 10.43 & 10.22 & 129 & 128 \\
\hline Minimum value & 17.3 & 17.0 & 6.40 & 6.00 & 72 & 68 \\
\hline Maximum value & 29.4 & 28.8 & 15.30 & 15.55 & 198 & 197 \\
\hline Interval & 12.1 & 11.8 & 8.90 & 9.55 & 154 & 129 \\
\hline Standard deviation & 3.3 & 3.2 & 2.5 & 2.5 & 38.3 & 35.4 \\
\hline Coefficient of variation [\%] & 13 & 13 & 24 & 25 & 30 & 28 \\
\hline \multicolumn{7}{|c|}{ Bocian Pond } \\
\hline Average & 24.3 & 23.8 & 12.02 & 12.07 & 149 & 152 \\
\hline Minimum value & 16.7 & 16.6 & 9.86 & 10.10 & 131 & 126 \\
\hline Maximum value & 30.5 & 29.8 & 21.15 & 19.74 & 167 & 171 \\
\hline Interval & 13.8 & 13.2 & 11.29 & 9.64 & 36 & 45 \\
\hline Standard deviation & 3.8 & 3.7 & 1.6 & 1.5 & 11.3 & 11.7 \\
\hline Coefficient of variation [\%] & 16 & 16 & 13 & 13 & 8 & 8 \\
\hline
\end{tabular}


oxygen, but the differences between the values are small. The standard deviation values, evidencing diversification between the observations and mean, reached higher values for the features measured close to the water surface. Both in case of the degree of oxygen saturation. the content of dissolved oxygen and temperature, higher values of standard deviation were registered in Mydlniki II pond water (Table 1). Values of water temperature are strictly connected with the thermal values of the atmospheric air. Water temperature both near the pond surface and its bottom was growing with increasing air temperature. Average values of water temperatures close to the pond bottom were by about $0.5^{\circ} \mathrm{C}$ lower than by the surface. Also minimum and maximum values were always slightly lower in the benthic water. The differences between these values and the median are not significant, which is caused by a constant water circulation in the pond, resulting among others from the movement of the organisms living in ponds. The effect of water facilities or atmospheric conditions. The analyzed ponds do not reveal thermal stratification due to their small depth (up to $2 \mathrm{~m}$ ).

Content of oxygen dissolved in water is counted among the most important water indices conditioning the possibility of fish farming and influencing the farm profitability. Oxygen demands for carp range from 4 to $7 \mathrm{mg} \cdot \mathrm{dm}^{-3}$ at the optimal value of $5 \mathrm{mg} \cdot \mathrm{dm}^{-3}$ [Bieniarz et al. 2003]. Carp is classified to fish resistant to oxygen content in water, however, insufficient oxygen level may be the cause of many diseases, some of them lethal. The research was conducted in July and August, when oxygen conditions are most unfavourable due to high temperatures. Despite that fact, the content of oxygen dissolved in the pond water was always higher than the minimal values conditioning fish welfare. The content of oxygen dissolved in water of both ponds was higher in July. In Mydlniki II close to the surface average oxygen concentration was $14.02 \mathrm{mg} \cdot \mathrm{dm}^{-3}$, whereas close to the bottom $13.57 \mathrm{mg} \cdot \mathrm{dm}^{-3}$. In August average oxygen amount was respectively 8.96 and $9.02 \mathrm{mg} \cdot \mathrm{dm}^{-3}$. In Bocian, in July average amount of dissolved oxygen near the surface and the bottom was the same $12.32 \mathrm{mg} \cdot \mathrm{dm}^{-3}$. In August average oxygen concentrations were on the level of $11.71 \mathrm{mg} \cdot \mathrm{dm}^{-3}$ close to the water table and $11.80 \mathrm{mg} \cdot \mathrm{dm}^{-3}$ near the bottom.

In reservoirs of small depth, such as the investigated fish ponds, water saturation with oxygen may assume the values several times higher than full saturation. This state, described as oxygen over-saturation, results mainly from the amount of solar exposure which affects the intensity of plant development in the reservoir. In Mydlniki II the degree of saturation was characterized by the greatest variability among the analyzed indices. Maximum value was $198 \%$ close to the surface and 197\% near the bottom of the pond (Table 1). The lowest oxygen saturation in the pond $-68 \%$ close to the surface was registered during the period from 14 to $16 \mathrm{Au}$ gust and $69 \%$ from 17 to 18 August close to the reservoir bottom. Variation coefficient of oxygen saturation in water close to the surface and near the bottom of Bocian production pond was the same. The degree of oxygen saturation close to the pond bottom was the lowest on 9 August (126\%), whereas close to the surface on $13 \mathrm{Au}-$ gust (126\%); the values exceeded full saturation. Research of Woźniewski [1992] on the effect of oxygen saturation on live activities of cyprinid fish revealed the oxygen optimum on the level of 96-178\%. The lowest required saturation ranges from 20 to $50 \%$, but its decline below $20 \%$ may prove fatal for carp.

In Mydlniki II pond the relationship between the temperature and dissolved oxygen revealed a positive linear correlation. Pearson's coefficient $r=0.83$ in the near-surface water and $r=0.81$ close to the pond bottom pointed to a very high correlation between these indices (Figure 1).

In Bocian pond, a very weak linear correlation was demonstrated between water temperature and dissolved oxygen. Coefficient $r=0.1$ in near-surface water and -0.02 close to the pond bottom (Figure 2). The correlation between the degree of oxygen saturation and water temperature in the secondary pond revealed a similar relationship as in case of dissolved oxygen. Person's coefficient between the indices was 0.88 near water surface and $r=0.89$ near the bottom points, which evidences a very high correlation (Figure 3).

Correlation between the degree of oxygen saturation and water temperature in the production pond showed a slightly lower linear correlation. Linear relationship is positive which denotes that the degree of oxygen saturation is incrementing with growing water temperature. Correlation coefficient near the surface was $r=$ 0.69 , while $r=0.53$ near the bottom point to a high correlation (Figure 4). 
a)

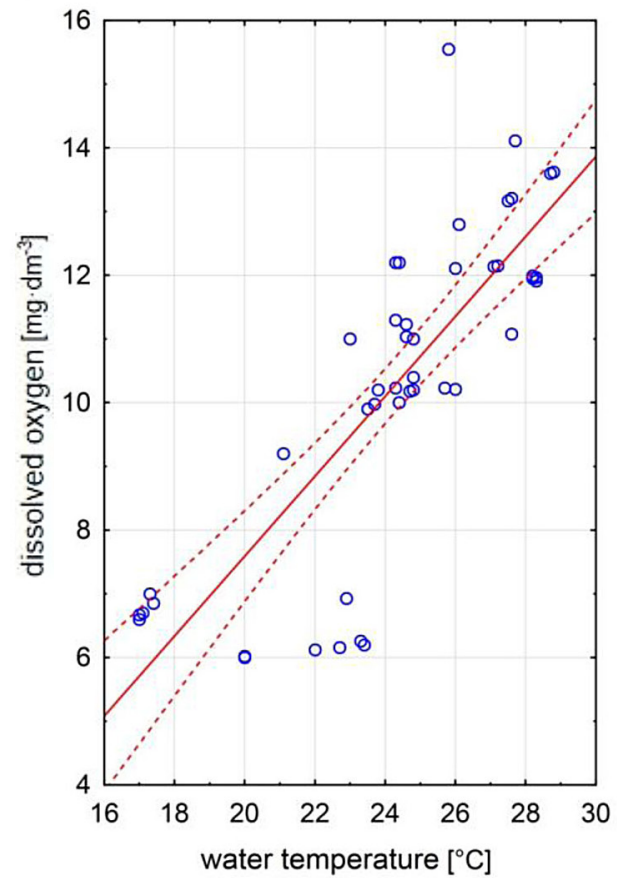

b)



Figure 1. Correlational relationship between dissolved oxygen and water temperature near the surface (a) and bottom (b) in Mydlniki II pond

a)

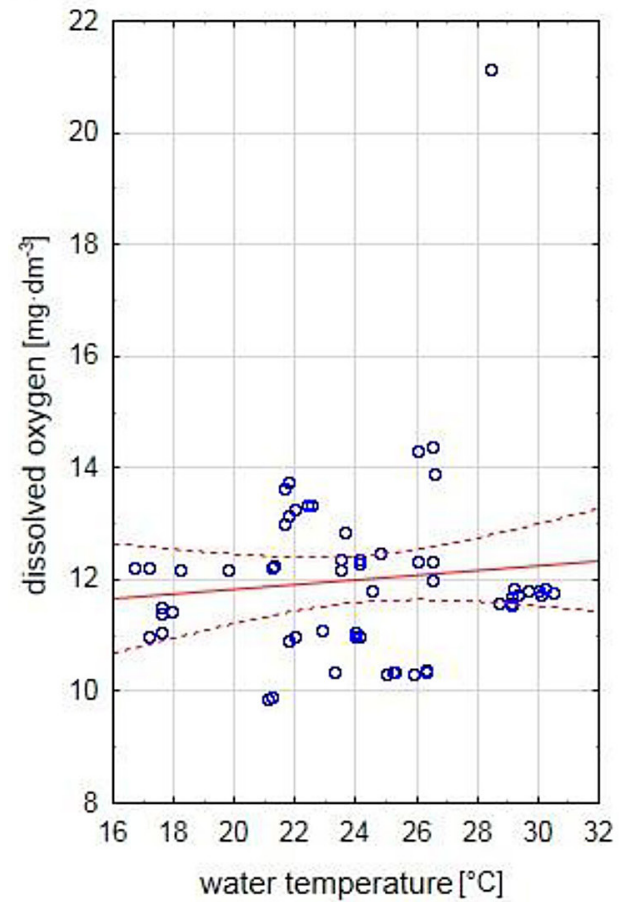

b)



Figure 2. Correlational relationship between dissolved oxygen and water temperature near the surface (a) and bottom (b) in Bocian pond

In order to verify statistical significance of differences between values of indices for both ponds normality of distributions was checked using Sahpiro-Wilk test at significance level $\alpha=$ 0.05 . Due to a lack of distribution, normality of the values of all tested indices, the significance of differences was computed by means of U MannWhitney nonparametric test [Stanisz 2006]. At significance level $\alpha=0.05$ it was revealed that the values are statistically significantly different for dissolved oxygen and degree of oxygen saturation where the probability $p$ was lower than 
a)

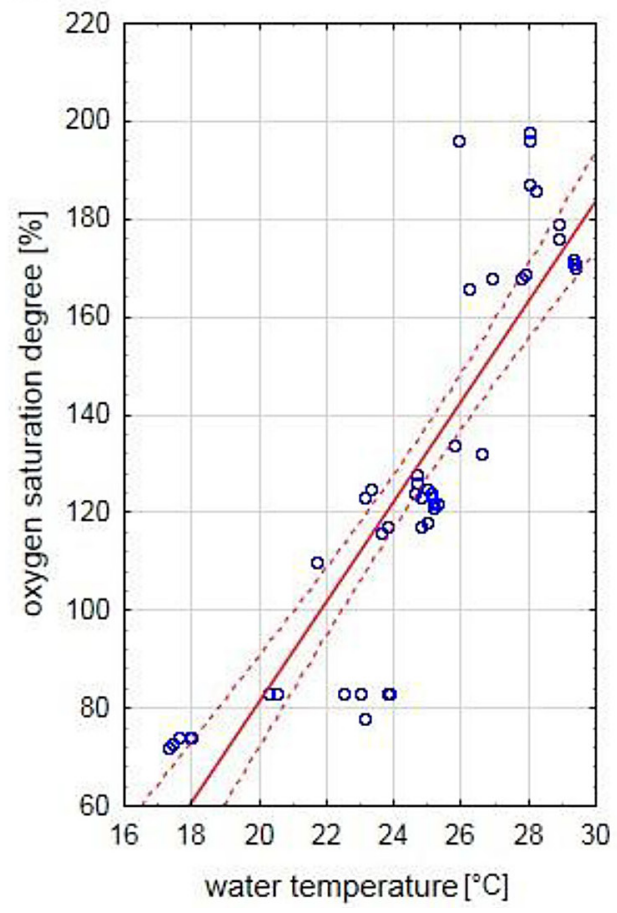

b)

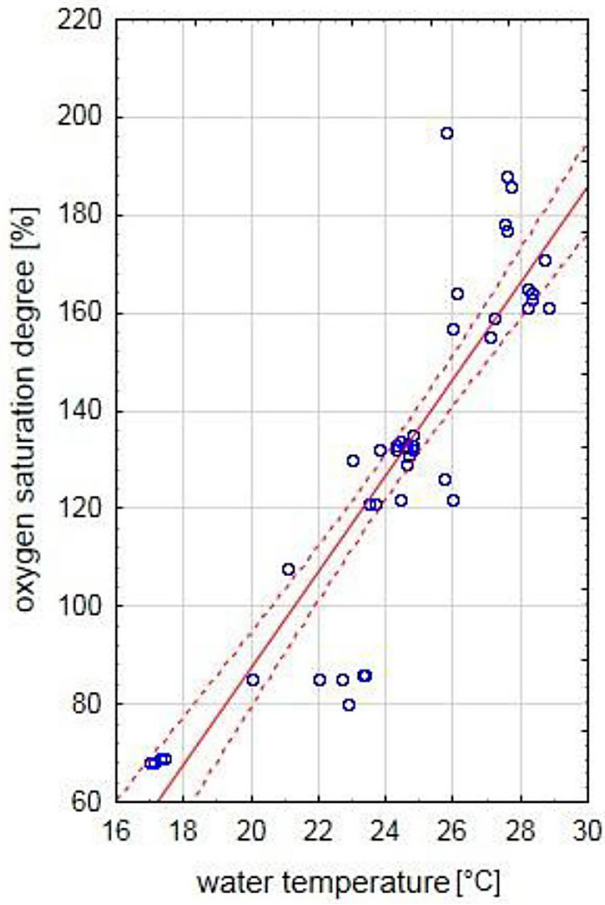

Figure 3. Correlational relationship between oxygen saturation degree and water temperature near the surface (a) and bottom (b) in Mydlniki II pond

a)

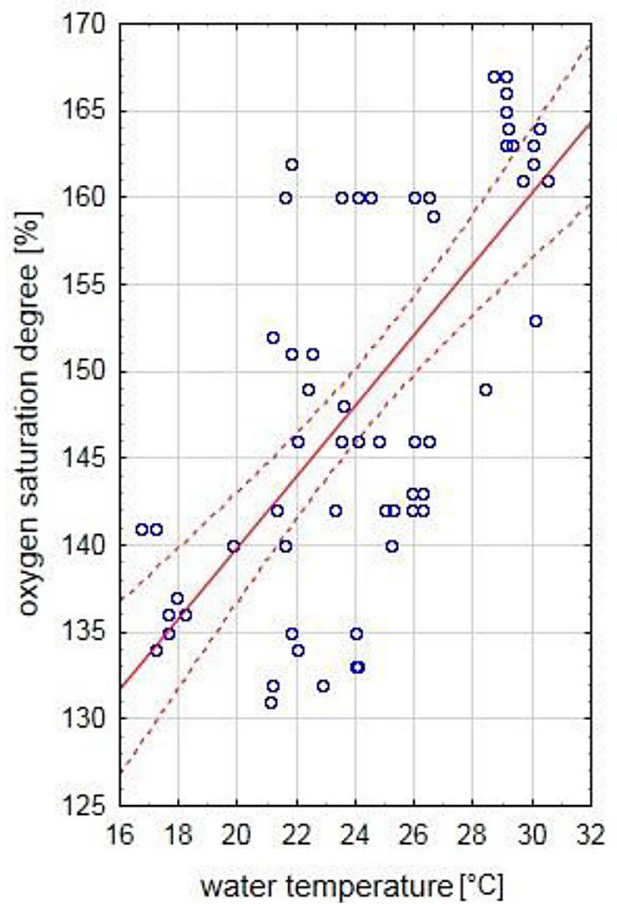

b)

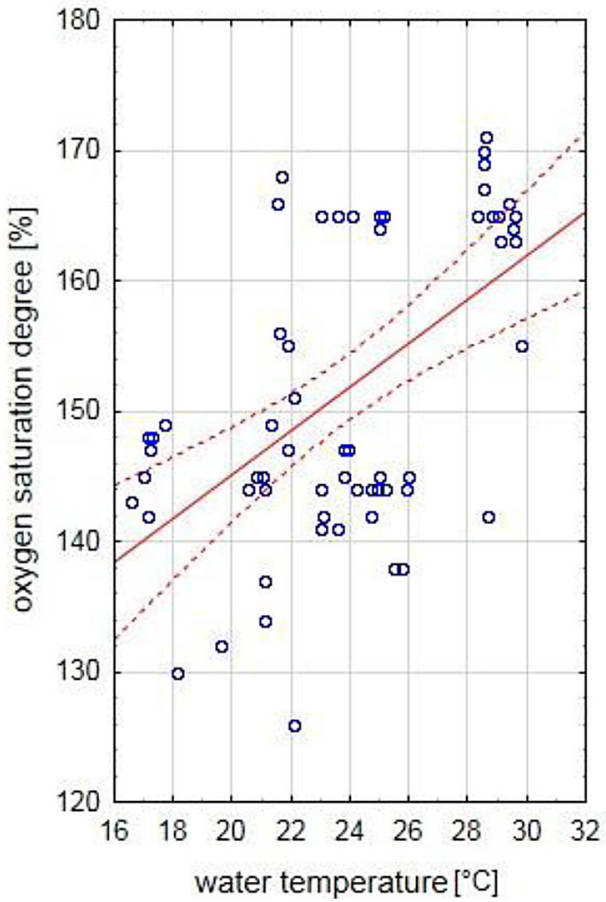

Figure 4. Correlational relationship between oxygen saturation degree and water temperature near the surface (a) and bottom (b) in Bocian pond

the assumed significance level both near the surface and close to the bottom of both ponds. A lack of significant differences in the analyzed samples was found for water temperature both close to the water table and near the reservoir bottom. Statistical analysis showed that the values of dissolved oxygen and the degree of oxygen saturation are significantly higher in water of Bocian pond in comparison with Mydlniki II pond (Table 2). 
Table 2. Significances concerning water quality between analyzed ponds

\begin{tabular}{|c|c|c|c|c|c|}
\hline \multirow{2}{*}{ Indices of water quality } & \multirow{2}{*}{\multicolumn{2}{|c|}{ Fish pond }} & \multirow{2}{*}{ Median } & \multicolumn{2}{|c|}{ Probability level } \\
\hline & & & & Shapiro-Wilka & U Manna-Whitneya \\
\hline \multirow{4}{*}{ Water temperature $\left[{ }^{\circ} \mathrm{C}\right]$} & \multirow{2}{*}{ near the surface } & Mydlniki II & 25.0 & 0.027 & \multirow{2}{*}{0.265} \\
\hline & & Bocian & 24.1 & 0.011 & \\
\hline & \multirow{2}{*}{ near the bottom } & Mydlniki II & 24.4 & 0.010 & \multirow{2}{*}{0.298} \\
\hline & & Bocian & 23.9 & 0.031 & \\
\hline \multirow{4}{*}{$\begin{array}{l}\text { Dissolved oxygen } \\
{\left[\mathrm{mg}^{\left.-\mathrm{dm}^{-3}\right]}\right.}\end{array}$} & \multirow{2}{*}{ near the surface } & Mydlniki II & 10.00 & 0.000 & \multirow{2}{*}{0.000} \\
\hline & & Bocian & 11.80 & 0.002 & \\
\hline & \multirow{2}{*}{ near the bottom } & Mydlniki II & 10.23 & 0.000 & \multirow{2}{*}{0.000} \\
\hline & & Bocian & 11.89 & 0.001 & \\
\hline \multirow{4}{*}{$\begin{array}{l}\text { Oxygen saturation degree } \\
{[\%]}\end{array}$} & \multirow{2}{*}{ near the surface } & Mydlniki II & 123 & 0.001 & \multirow{2}{*}{0.000} \\
\hline & & Bocian & 146 & 0.001 & \\
\hline & \multirow{2}{*}{ near the bottom } & Mydlniki II & 132 & 0.015 & \multirow{2}{*}{0.000} \\
\hline & & Bocian & 147 & 0.030 & \\
\hline
\end{tabular}

\section{CONCLUSIONS}

The analysis of results obtained from investigations of water features on various depths in secondary and production ponds in the summer season allowed to formulate the following conclusions:

1. Water temperature in ponds oscillated within the $16.6-30.5{ }^{\circ} \mathrm{C}$ range and was optimal for development and keeping cyprinid fish. Mean water temperature in secondary ponds was about $0.4{ }^{\circ} \mathrm{C}$ higher than in the production pond, which is beneficial for younger fish farming, which require slightly higher water temperature than older fish.

2. In July, oxygen saturation in water of fish ponds exceeded the optimum upper limit value $(168 \%)$ on a few dates, however, it posed no lethal threat for fish. In August oxygen saturation fell within the range of optimal values, creating better conditions for fish development. In August only in the secondary pond it was found that oxygen saturation in water on 12 dates was lower than the low optimal value $(96 \%)$. Minimum oxygen saturation in water was $68 \%$ and was much higher than the value critical for carp (20\%).

3. Irrespective of the depth from which water was sampled in fish ponds, its concentrations of dissolved oxygen and degree of oxygen saturation were increasing with growing water temperature. Correlation coefficient between the degree of oxygen saturation and water temperature showed a very high linear correlation.
3. Significantly higher values of dissolved oxygen concentrations and degree of oxygen saturation were registered in the production pond than in the secondary pond. Bigger differences of the medians of indices between the ponds occur in near-surface than in benthic waters. The differences for dissolved oxygen near the surface and near the bottom are respectively 1.80 and $1.66 \mathrm{mg} \cdot \mathrm{dm}^{-3}$ and degree of oxygen saturation 23 and $15 \%$.

\section{REFERENCES}

1. Bieniarz K., Konwnacki A., Epler P. 2003. Biologia stawów rybnych. IRŚ, Olsztyn.

2. Dulic G., Subakov-Simic G., Ciric M., Relic R., Lakic N., Stankovic M., Markovic Z. 2010. Water quality in semi-intensive carp production system using three different feeds. Bulg. J. Agric. Sci., 16 (3), 266-274.

3. Gál D., Szabó P., Pekár F., Váradi L. 2003. Experiments on the nutrient removal and retention of a pond recirculation system. Hydrobiologia, 506509 (1-3), 767-772.

4. Jawecki B. 2008. Dobowe ekstrema tlenowe w stawie rybnym. Zesz. Prob. Post. Nauk Rol., 528, 373-379.

5. Jawecki B., Jaroszewicz-Smyk T., Drabiński A. 2013. The spatial variation of oxygen condition in carp pond located in nature reserve ,Stawy Milickie". J. Water Land Dev., 19 (VII-XII), 47-52.

6. Jawecki B., Krzemińska A. 2008. Wpływ temperatury wody na natlenienie strefy eufotycznej stawu karpiowego. Zesz. Probl. Post. Nauk Rol., 528, 381-387. 
7. Kanclerz J. 2005. Wpływ stawów rybnych (karpiowych) na jakość wód odpływających ze zlewni. Zesz. Nauk. Wydz. Budow. i Inż. Środ. Koszalin, 22, 823-833.

8. Kanownik W. 2010. Jakość wód zasilających i w toni stawów rybnych w okresie hodowlanym. Zesz. Prob. Post. Nauk Rol., 548, 283-291.

9. Kanownik W., Policht-Latawiec A. 2015. Changeability of oxygen and biogenic indices in waters flowing through the areas under various anthropopressure. Pol. J. Environ. Stud., 24 (4), 1633-1640.

10. Krzyczkowski P. 2000. Wpływ wybranych warunków meteorologicznych na kształtowanie się temperatury w stawie karpiowym. Rozprawa doktorska. AR we Wrocławiu, ss. 70.

11. Lutnicka H. 2011. Skład chemiczny wód powierzchniowych a zdrowotność ryb. Zesz. Nauk. UP Wroc., Biol. Hod. Zwierz., LXIII, 583, 192-203.

12. Łysak A., Węglarzy K., Wrona J. 2002. Analiza zmieniającej się czystości wód zasilających a wydajność stawów rybnych. Zesz. Nauk. AR w Krakowie.
Inżynieria Środowiska, 393(23), 187-200.

13. Raczyńska M., Machula S. 2006. Abiotic conditions in carp ponds. Ecological Chemistry and Engineering, 13(8), 779-785.

14. Stanisz A. 2006. Przystępny kurs statystyki z zastosowaniem STATISTICA PL na przykładach z medycyny. Tom 1. Statystyki podstawowe. StatSoft. Kraków.

15. Tokarczyk-Dorociak K., Drabiński A. 2007. Dynamika zmian warunków świetlnych w stawie karpiowym w okresie hodowlanym. Przegląd Naukowy, Inżynieria i Kształtowanie Środowiska, SGGW, XVI, 1(35), 93-102.

16. Whetstone J. 2009. Managing farm ponds for fishing. Clemson Extension. Fact Sheet 19. Forestry and Natural Resources.

17. Woźniewski M. 1992. Warunki tlenowe w chowie i hodowli ryb karpiowatych. Wytyczne do oceny jakości wód przydatnych do chowu i hodowli ryb karpiowatych. Wydawnictwo AR we Wrocławiu, 21-30. 